\title{
Activities of $\alpha$-galactosidase and polygalacturonase during hydration of Dalbergia nigra ((Vell.) Fr All. ex Benth.) seeds at different temperatures ${ }^{1}$
}

\author{
Glauciana da Mata Ataíde²*, Eduardo Euclydes de Lima e Borges², \\ José Francisco de Carvalho Gonçalves ${ }^{3}$, Valéria Monteze Guimarães ${ }^{4}$, \\ Elisa Monteze Bicalho ${ }^{5}$, Andressa Vasconcelos Flores ${ }^{6}$
}

\begin{abstract}
Germination is a process that begins with seed water uptake, stimulating enzyme synthesis or activating enzymes already present. The objective of this study was to evaluate variations in monosaccharide reserves and the activities of the $\alpha$-galactosidase and polygalacturonase enzymes during the hydration of two lots of Dalbergia nigra (Bahia Rosewood) seeds. Seeds from different origins constituted the two lots I and II, classified as high and low vigor, respectively. Both lots were placed in desiccators with a high relative humidity to hydrate and at 15 and $25{ }^{\circ} \mathrm{C}$ until levels of $10,15,20$ and $25 \%$ moisture levels in seeds were reached. The seed cotyledons were analyzed for the quantity of monosaccharides and enzyme activity. The control had higher concentrations of xylose and rhamnose, which decreased during hydration until the $15 \%$ level was reached, after which concentrations increased again in both lots. Lot I, with a superior quality, showed higher glucose synthesis and degradation during seed hydration. Both enzymes were pre-existing since activity was already present in the seeds without imbibition. The polygalacturonase enzyme increased and the $\alpha$-galactosidase enzyme remained relatively constant during seed hydration.
\end{abstract}

Index terms: imbibition, Bahia Rosewood, biochemical modifications, monosaccharides.

\section{Atividades de $\alpha$-galactosidase e poligalacturonase durante a hidratação de sementes de Dalbergia nigra ((Vell.) Fr. All. ex Benth.) sob diferentes temperaturas}

\begin{abstract}
RESUMO - A germinação é um processo que se inicia com a absorção de água pelas sementes, estimulando a síntese de enzimas ou ativação daquelas pré-existentes. O objetivo deste trabalho foi estudar as variações nas reservas de monossacarídeos e atividades das enzimas $\alpha$-galactosidase e poligalacturonase durante a hidratação de sementes de dois lotes de Dalbergia nigra (jacarandá-da-Bahia). Para tanto, sementes de duas procedências constituíram os lotes I e II, classificados como de alto e baixo vigor, respectivamente. Os lotes foram colocados para hidratar em dessecadores com alta umidade relativa nas temperaturas de 15 e $25^{\circ} \mathrm{C}$ até atingirem os níveis de hidratação de 10, 15, 20 e $25 \%$ de umidade nas sementes. Os teores de monossacarídeos e as atividades das enzimas foram analisados nos cotilédones das sementes. Os teores de ramnose e xilose apresentaram valores superiores na testemunha, com redução durante a hidratação até $15 \%$, momento a partir do qual aumentaram novamente, em ambos os lotes. O lote I, de qualidade superior, possui maior síntese e degradação de glicose durante a hidratação das sementes. Ambas as enzimas mostraram ser pré-formadas, por já apresentarem atividade nas sementes sem embebição. A poligalacturonase aumentou e a $\alpha$-galactosidase manteve-se relativamente constante durante a hidratação das sementes.
\end{abstract}

Termos para indexação: embebição, jacarandá-da-Bahia, modificações bioquímicas, monossacarídeos.

\section{Introduction}

The germination process is a complex and ordered series of physiological and biochemical events, starting with renewed embryo growth and the subsequent rupture of the integument by the radicle (Nonogaki et al., 2007).

\footnotetext{
'Submitted on 05/08/2012. Accepted for publication on 09/26/2012. ${ }^{2}$ Laboratório de Sementes Florestais, Departamento de Engenharia Florestal, Universidade Federal de Viçosa, 36570-000 - Viçosa, MG, Brasil

${ }^{3}$ Laboratório de Fisiologia e Bioquímica Vegetal, Instituto Nacional de Pesquisas da Amazônia, 69060-001 - Manaus, AM, Brasil.

${ }^{4}$ Departamento de Bioquímica e Biologia Molecular, Universidade Federal de Viçosa, 36570-000 - Viçosa, MG, Brasil.
}

${ }^{5}$ Departamento de Biologia Vegetal, Universidade Federal de Minas Gerais, 31270-901 - Belo Horizonte, Brasil.

${ }^{6}$ Instituto Federal de Educação, Ciência e Tecnologia de Mato Grosso, 78106-960 - Cáceres, MT, Brasil.

*Corresponding author < glaucianadamata@yahoo.com.br> 
Germination is influenced by external factors, such as light, temperature, and water and oxygen availability, as well as by internal factors, such as germination inhibitors and promoters, which can act alone or in combination with the other factors (Borges and Rena, 1993).

Seed hydration results in increased metabolic activity, stimulating the synthesis of enzymes or the activation of preexisting ones, with mobilization of reserves and digestion of the cell wall, weakening it and causing a consequent rupture of the integument by the radicle (Baskin and Baskin, 1998). During the germination process, several enzymes are involved in metabolic reactions of molecule synthesis and degradation. The hydrolytic enzyme $\alpha$-galactosidase acts in the mobilization of polysaccharides and cell wall components and in oligosaccharides of the raffinosic series, and its degradation products are used to generate energy and produce raw materials for germination, among other things (Buckeridge et al., 2004). The activity of the $\alpha$-galactosidase enzyme increased during the germination of Tachigali multijuga seeds, being related to the capacity to hydrolyze oligosaccharides, such as raffinose, stachyose and galactomannan polymers, indicating a special role during germination (Fialho et al., 2008). According to Polowick et al. (2009), after super expression of the $\alpha$-galactosidase gene in Pisum sativum seeds, the lines showed significant reductions in oligosaccharides, specifically raffinose and stachyose, and germination rates were $96 \%$.

Among the main enzymes which degrade cell wall pectin compounds, are the polygalacturonases (PG), which hydrolyze the $\alpha-1,4$ glycoside bonds between two residues of galacturonic acid of the pectin chain (Swain et al., 2011). Their activity is correlated with an increase in soluble pectins and changes in the pericarp texture during fruit maturation (Ghiani et al., 2011). It is thought that the polygalacturonase enzyme acts in pectin degradation during germination, softening the integument for protrusion of the radicle (Kanai et al., 2010).

Dalbergia nigra ((Vell.) Fr. All. ex Benth.), popularly known as Bahia Rosewood, is a semi-heliophilous, arboreal species, which grows in the Atlantic Forest and belongs to the Leguminosae Papilonoideae family (Lorenzi, 1992). In plant succession, it is classified as a late secondary to climax species and is considered suitable for mixed plantings on degraded, permanently conserved land (Donadio and Demattê, 2000). Its wood is moderately hard, heavy, decorative and naturally long lasting, and can be used to make musical instruments, such as pianos (Carvalho, 2003). Due to its valued wood and heavy logging, this species is currently on the Brazilian list of species threatened with extinction, classified in the vulnerable category (Ibama, 2008), so that the implementation of plans for its genetic conservation is urgent.

Considering the ecological importance of this species, its potential economic uses with sustainable management, associated with the need to better understand the factors involved in seed germination, the objective of this research was to study the variations in monosaccharide reserves and the activities of the $\alpha$-galactosidase and polygalacturonase enzymes during the hydration of two lots of Dalbergia nigra seeds.

\section{Materials and Methods}

The present study was done at the Laboratory of Forestry Seed Analysis, Forestry Department of the Federal University of Viçosa, Viçosa, Minas Gerais State, Brazil. Seeds of Dalbergia nigra were collected at two different sites in Viçosa, denoted lots I and II. Immature, deteriorated and damaged seeds were eliminated during cleaning. The selected seeds were kept in wood fiber drums and stored in a cold chamber at $5{ }^{\circ} \mathrm{C}$ and $60 \% \mathrm{RH}$ for two months.

Seeds from both lots were placed to germinate on two leaves of germitest paper in Petri dishes moistened with 4.0 $\mathrm{mL}$ of distilled water at $25^{\circ} \mathrm{C}$, in continuous light from four $40 \mathrm{~W}$ daylight-type bulbs, for 12 days (Ferraz-Grande and Takaki, 2001). The substrates were kept humid during the experiment. The percentage germination was calculated by counting daily those seeds which emitted a radicle and the germination speed index (GSI), from the formula proposed by Maguire (1962).

Seed samples from lots I and II were hydrated by keeping them in desiccators with a relative humidity of $95-99 \%$ at 15 and $25{ }^{\circ} \mathrm{C}$, until approximately four levels of humidity were reached: 10, 15, 20 and 25\%. The hydration of the seeds up to the desired amount of water was calculated from the initial water content of 7.92 and $8.98 \%$ for lots I and II, respectively, and from the initial weight of the seed samples, as in the equation below (Cromarty et al., 1990):

where: $\mathrm{M}=$ weight of desired content of water $(\mathrm{g}) ; \mathrm{Mi}=$ weight of original content of water $(\mathrm{g}) ; \mathrm{CA}_{1}=$ original water content (percentage on a wet basis); $\mathrm{CA}_{2}=$ desired water content (percentage on a wet basis).

After reaching the desired moisture levels, corresponding to phases I and II of the absorption curve of the water by the seeds during germination, the samples were removed for analysis of the monosaccharides and enzyme activity.

Analysis of the monosaccharides: monosaccharides were extracted from the cotyledons according to the methodology described by Black et al. (1996), but with modifications: the dry, ground-up material was homogeneized with $80 \%$ ethanol at $75{ }^{\circ} \mathrm{C}$ for 30 minutes, then centrifuged for 10 minutes at $16000 \mathrm{xg}$. The supernatant liquid with the sugars was separated and this stage of the extraction was repeated four 
more times, for homogeneization of the precipitate with $80 \%$ ethanol. The supernatants were mixed, completely dried and added to $1.0 \mathrm{~mL}$ of distilled water. Then, $500 \mu \mathrm{L}$ aliquotes were taken from the samples to prepare the alditol acetates, used in monosaccharide analysis with gas chromatography. A mixture containing the sugars glycose, galactose, mannose, xylose, arabinose and rhamnose was also prepared, serving as Standards for comparing with the sample.

Quantification was made according to Englyst and Cummings (1984), using Shimadzu GC14-A gas chromatography, equipped with a flame ionization detector (FID), linked to a C-R6A chromatopac recorder and integrator. The gas flow was $0.25 \mathrm{~mL} \cdot \mathrm{min}^{-1}$, with the temperatures of the injector, detector and column at 250,220 and $275{ }^{\circ} \mathrm{C}$, respectively. After injection of the Standards, $1.0 \mu \mathrm{L}$ of alditol acetate was injected per sample. Three replications were made for each extract and measurement. The sugars were identified and measured by recording the concentration of each sugar on the integrator based on the retention area and time corresponding to the standard sugar and the results were printed on a chromatogram (Rodrigues et al., 2005).

Analysis of enzyme activity: the cotyledons were evaluated for the activities of the $\alpha$-galactosidase and polygalacturonase enzymes. The enzyme extracts were obtained by macerating $0.1 \mathrm{~g}$ of vegetable tissue in $1.5 \mathrm{~mL}$ of $100 \mathrm{mM}$ sodium acetate buffer, $\mathrm{pH} 5.0$, using a porcelain mortar in an ice bath. The samples were then centrifuged at $24,000 \mathrm{~g}$ for 20 minutes at $4{ }^{\circ} \mathrm{C}$, and the clear supernatant was used as an enzyme source as described by Guimarães et al. (2001).

$\alpha$-galactosidase enzyme trial: the activity of the $\alpha$-galactosidase enzyme was determined by adding $20 \mu \mathrm{L}$ of crude enzyme extract to a reaction medium composed of $730 \mu \mathrm{L}$ of $100 \mathrm{mM}$ sodium acetate buffer, $\mathrm{pH} 5.0$ and $250 \mu \mathrm{L}$ of $2 \mathrm{mM}$ p-nitrophenyl- $\alpha$-D-galactopyranoside (p-NPGal). The reaction was conducted for 15 minutes in a water bath at $37^{\circ} \mathrm{C}$, being interrupted by the addition of $1 \mathrm{~mL}$ of 0.5 $\mathrm{M}$ sodium carbonate solution. The reading was taken at 410 $\mathrm{nm}$, with an enzyme unit being defined as the quantity of protein necessary to produce one $\mu \mathrm{mol}$ of p-nitrophenol per minute under the trial conditions (Guimarães et al., 2001). The absorbance values obtained were transformed to $\mu$ moles of p-nitrophenolate, using a standard curve constructed with 0-0.20 $\mu$ moles of p-nitrophenol (p-NP).

Polygalacturonase enzyme trial: to evaluate the activity of polygalacturonase enzyme, the standard trial was based on the dosage of reducing sugar produced according to the DNS method (3,5 dinitrosalicylic), described by (Miller, 1959). The substrate used was $0.3 \%$ polygalacturonic acid from oranges to evaluate enzyme activity. The reaction mixture was composed of $1500 \mu \mathrm{L}$ of buffer extraction, $100 \mu \mathrm{l}$ of enzyme extraction and $350 \mu \mathrm{L}$ of substrate. The tubes with the solution were kept in a water bath at $40{ }^{\circ} \mathrm{C}$ for 60 minutes, the reaction being interrupted by adding $1.0 \mathrm{~mL}$ of DNS solution and boiling for 5 minutes, after which $2.0 \mathrm{~mL}$ of distilled water were added. Absorbance readings were taken at $540 \mathrm{~nm}$, with one enzyme unit being defined as the quantity of protein necessary to produce a $\mu$ mol equivalent of glycose per minute.

Experimental design and statistical procedure: the experimental design was completely random (DIC), composed of a $2 \times 4 \times 2$ factorial (two lots, four levels of hydration and two temperatures), with the control as an additional treatment. The trials for determining enzyme activity were done in triplicate, with three replications per treatment. Analyses of variance were done for the germination and GSI variables and the means were compared using the Tukey test at the 5\% probability level. The levels of monossacharides were analyzed with regression analyses and the significance tested with the $t$ test at the $5 \%$ level using the Statistica program (Statsoft, 2008).

\section{Results and Discussion}

The results for the germination and germination speed index showed that the physiological quality of the lot I seeds was statistically superior to that of lot II, with germination percentages of $80 \%$ and $33 \%$ respectively (Figure 1). The germination speed index of the lot I seeds was also greater than for lot II, with GSI means of 1.85 and 0.74 , respectively. Therefore, the lot I seeds of Dalbergia nigra could be classified as having a high vigor compared to a low vigor for lot II.
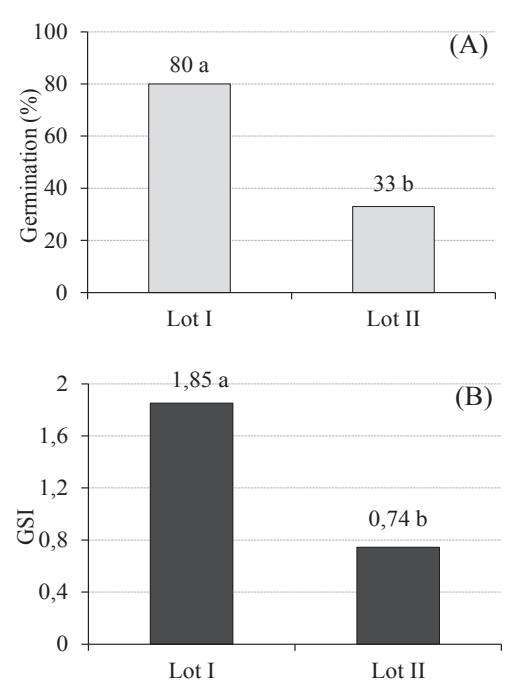

Figure 1. Germination percentage (A) and germination speed index (GSI) (B) of Dalbergia nigra seeds lots I and II.

*Means followed by the same letter did not differ between themselves at the $5 \%$ level according to the Tukey test. 
The concentrations of monosaccharides in the seed cotyledons of Dalbergia nigra were affected by the different moisture levels (Figure 2). At the hydration temperatures of 15 and $25^{\circ} \mathrm{C}$, the tendency curves were similar for each lot. The concentrations of the galactose and glycose sugars in lot I increased up to a hydration level of $15 \%$, decreasing thereafter. Rhamnose and xylose produced opposite results, with higher values in the control and a reduction during hydration up to a level of $15 \%$, after which they increased again. In the low vigor lot II, the variations in the concentrations of the galactose, rhamnose and xylose sugars were similar to those of lot I, while those of glycose were different between the lots, both in quantity and tendency.
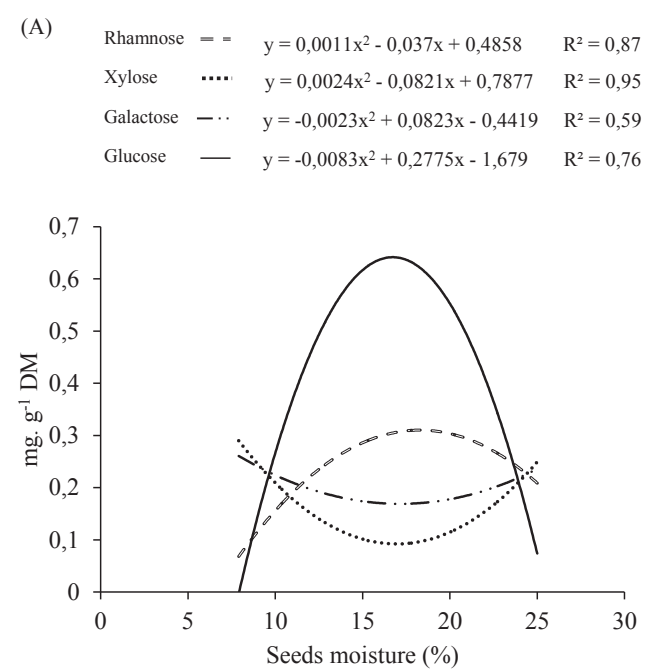

(C)

$$
\begin{array}{lll}
\text { Rhamnose }== & \mathrm{y}=0,0006 \mathrm{x}^{2}-0,019 \mathrm{x}+0,4073 & \mathrm{R}^{2}=0,46 \\
\text { Xylose } \quad \cdots . . & \mathrm{y}=0,0023 \mathrm{x}^{2}-0,0804 \mathrm{x}+0,7714 & \mathrm{R}^{2}=0,97 \\
\text { Galactose }-. . & \mathrm{y}=-0,0031 \mathrm{x}^{2}+0,1101 \mathrm{x}-0,6606 & \mathrm{R}^{2}=0,72 \\
\text { Glucose }-\mathrm{y}=-0,001 \mathrm{x}^{2}+0,0301 \mathrm{x}-0,0122 & \mathrm{R}^{2}=0,13
\end{array}
$$

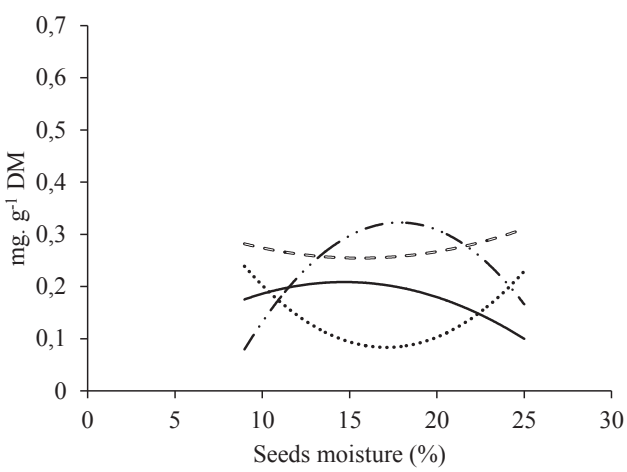

(B)
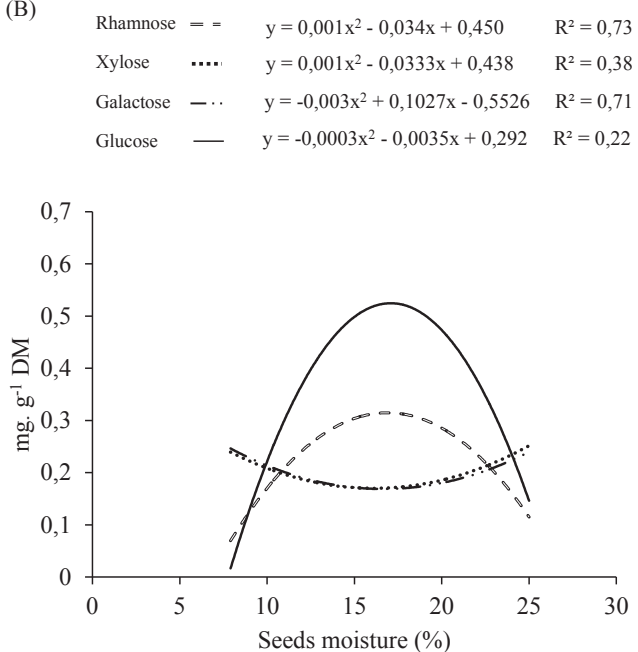

(D)
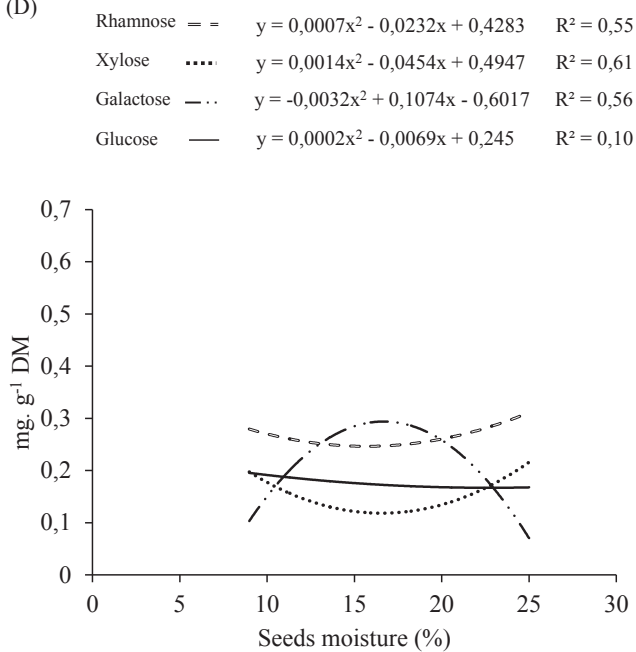

Figure 2. Concentration of monosaccharides (mg. $\mathrm{g}^{-1}$ of dry weight) in Dalbergia nigra seeds, during hydration at 15 and $25^{\circ} \mathrm{C}$. (A) Lot I $-15^{\circ} \mathrm{C}$. (B) Lot I $-25^{\circ} \mathrm{C}$. (C) Lot II $-15^{\circ} \mathrm{C}$. (D) Lot II $-25^{\circ} \mathrm{C}$.

The tendencies shown by rhamnose and xylose in lots I and II for both temperatures indicate that they may be in the process of being consumed by metabolism or being incorporated into the cell wall. From the similarity in the germination and distribution patterns of both monosaccharides in both lots, incorporation into the cell wall would seem to be the most reasonable explanation in this case, since expansion of the radicle needs this incorporation to increase wall flexibility for water to enter for hydration. Later, seed deterioration resulted in a lower use of both sugars, resulting in the accumulation observed. The glycose levels in lot I reached values of around 0.7 and $0.5 \mathrm{mg} . \mathrm{g}^{-1} \mathrm{MS}$ at 15 and $25^{\circ} \mathrm{C}$, respectively, whereas in lot II the maximum values seen were $0.2 \mathrm{mg} \cdot \mathrm{g}^{-1} \mathrm{MS}$ at both temperatures, decreasing for $15{ }^{\circ} \mathrm{C}$ and with the same tendency, but at lower values for $25{ }^{\circ} \mathrm{C}$. In the case of the less vigorous lot, it can be suggested that there was solute 
leakage to the apoplast or to the germination medium, seeing that the seeds had a lower physiological quality. Thus, in more deteriorated seeds, membrane permeability, especially the plasma membrane, would increase, resulting in glycose moving to the apoplast. The hydration of the lot II seeds was greater than in the more vigorous lot, reaching higher final values, so that water entry occurs not to the cell interior but to the apoplast determined by the presence of a high glycose content, which would be reducing the water potential of the seeds. In the more vigorous lot I seeds, the increase in glycose content may be due to amide degradation, whose rate of degradation by hydrolytic enzymes would increase with an increase in seed water content at a lower temperature, resulting in a greater accumulation with lower metabolic activity.

When comparing distinct genotypes of Zea mays, the genotypes which had a higher endogenous glycose content were those which had higher germination and initial seedling development (Oliveira Júnior et al., 2009). The authors emphasized that glycose exerts a strong influence on the germination process, reducing the effect of $\mathrm{ABA}$ on the inhibition of hydrolytic enzyme synthesis, favoring activation of the $\alpha$-amylase enzyme. Among the enzymes present in the embryos and cotyledons of Platymiscium pubescens, glycose was the only sugar detected during seed imbibition in PEG, and it is thought that this sugar is used in respiration and osmosis, resulting in more water absorption in the early stages of imbibition (Borges et al., 2002a). Also, in isolated embryos of Senna macranthera, a high concentration of glycose was observed in the dry seeds, with a significant increase after $72 \mathrm{~h}$ imbibition, with this increase being credited to the metabolism of other reserves, such as lipids and proteins (Borges et al., 2002b).

The levels of galactose showed similar patterns of variation in the two lots at both temperatures, indicating that temperature did not exercise any influence on its changes. The oligosaccharides of the raffinose family are reserves for rapid use, being the first to be mobilized by plants and used as an energy source during germination (Buckeridge et al., 2000; Molle and Tiné, 2009). The degradation of the oligosaccharides of the series results in a temporary accumulation of glycose and galactose in the cotyledons. Analyzing the mobilization of oligosaccharides of the raffinose series, there were accumulations of saccharose and free monosaccharides during the germination of Phaseolus aureus (Kuo et al., 1988) and Sesbania maginata (Buckeridge and Dietrich, 1996).

The activities of $\alpha$-galactosidase during hydration of the D. nigra seeds of lots I and II can be seen in Figure 3. Small differences were seen in the activities of the enzyme between the hydration temperatures of 15 and $25{ }^{\circ} \mathrm{C}$ in both lots (Figures 3A and 3B). The activity of $\alpha$-galactosidase was detected in the seeds even before imbibition, suggesting that this enzyme is pre-existing and present in the ripe seeds. The activities of the enzyme at both temperatures in lots I and II remained approximately constant, with a small reduction at $20 \%$ humidity for lot II. When comparing the activity data of the $\alpha$-galactosidase enzyme in the cotyledons with the increasing levels of galactose (Figure 2), which is one of the products resulting from the action of this enzyme, it can be seen that although the activity of the enzyme stays practically constant for all levels of water content in both lots, the increase in the concentration of galactose confirms the assumption that this accumulation does not come from the continual increase of product but from accumulation due to less use or leakage of the apoplast. The activity of $\alpha$-galactosidase increased during the germination of Tachigali multijuga seeds, associated with the reduction in raffinose and stachyose levels, so that seed hydration during imbibition possibly induced $\alpha$-galactosidase activity, resulting in a breakage of the oligosaccharids, which are indirectly involved in energy production (Fialho et al., 2008).

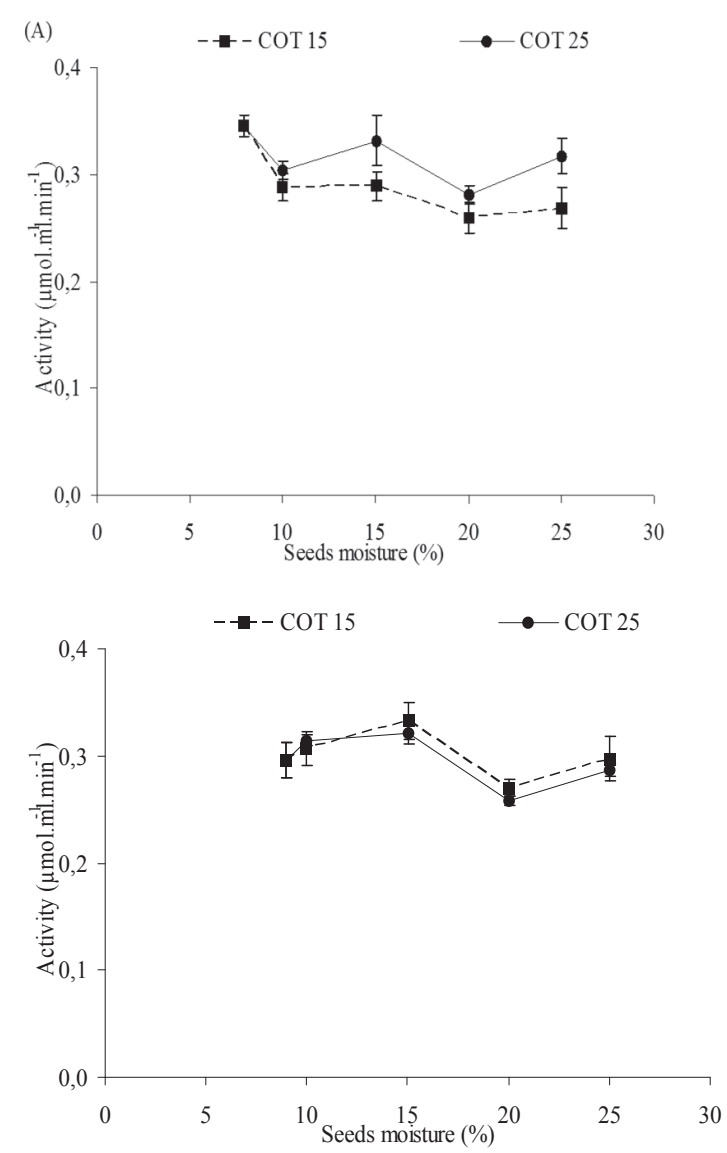

Figure 3 . Activity of the $\alpha$-galactosidase enzyme in cotyledons (COT) of Dalbergia nigra seeds lots I (A) and II (B) during hydration at 15 and $25^{\circ} \mathrm{C}$. 
The activity of polygalacturonase detected during hydration of the Dalbergia nigra seeds in the two lots evaluated indicates that this enzyme is pre-existing in both lots (Figure 4). There was a small reduction in activity of the enzyme at the $10 \%$ moisture content level for both temperatures in lot I, but with a continuous increase at higher moisture levels. On the other hand, activity increased continuously in lot II, independently of the temperature or seed water content. There was no relationship between the activities of the enzyme, at any temperature, with the values of galactose (Figure 2) at the different hydration levels. This may be explained by the polygalacturonase acting in the loss of cohesion between cells and the dissolution of the cell walls due to the removal of polygalacturonic acid. The action of polygalacturonase on the tissue cell walls of Dalbergia nigra seeds during imbibition was observed from the first day of imbibition, contributing to a reduction in the sugar components of the cell wall during imbibition (unpublished data).
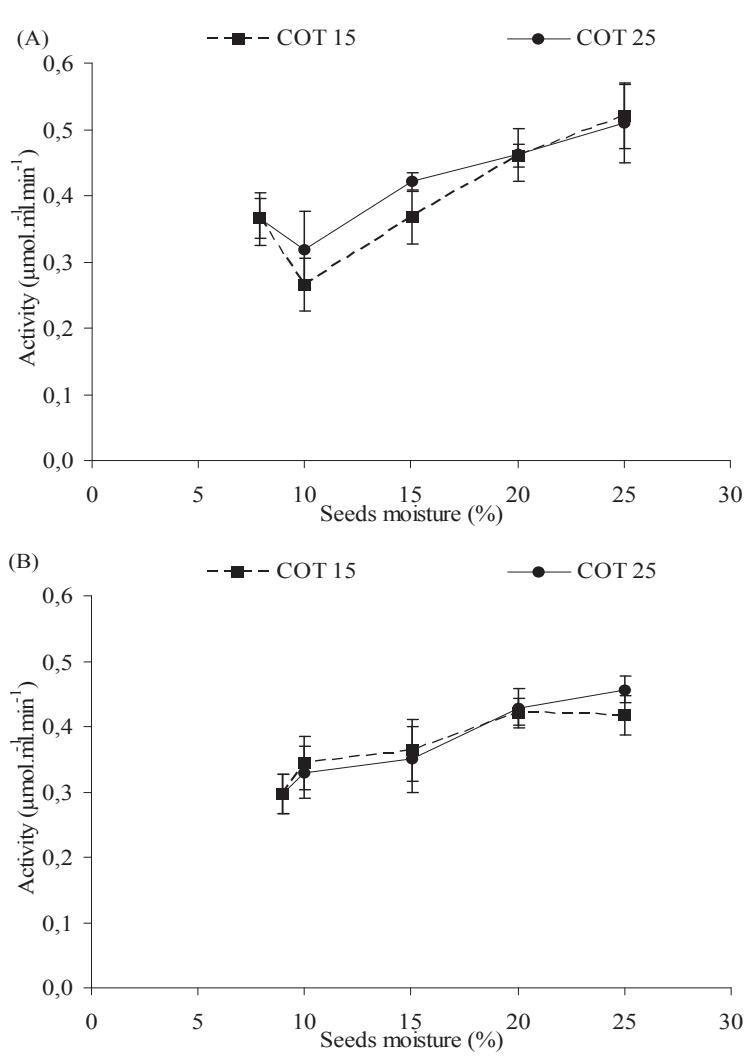

Figure 4. Activity of the polygalacturonase enzyme in cotyledons (COT) of Dalbergia nigra seeds lots I (A) and II (B) during hydration at 15 and $25^{\circ} \mathrm{C}$.

Magalhães etal.(2009) observed that the polygalacturonase enzyme is active even before imbibition by Schizolobium parahyba seeds, with an increase in activity in the embryonic axis and in the cotyledons close to germination (six to eight days), favoring cell expansion by reducing cell wall resistance to water entry and also by cell division. The activity of this enzyme also increased during imbibition in Lycopersicon esculentum seeds, being high when the seeds had completed germination (Sitrit et al., 1999). The authors believed that this enzyme was responsible for the mechanical weakening of the micropyle endosperm. However, polygalacturonase activity was not detected in the endosperm of Euphorbia heterophylla seeds during germination (Suda et al., 2003).

\section{Conclusions}

Higher vigor Dalbergia nigra seeds showed greater synthesis and degradation of glycose and galactose during hydration.

The activity of the $\alpha$-galactosidase enzyme in the cotyledons of $D$. nigra seeds is similar at 15 and $25^{\circ} \mathrm{C}$, and independent of seed vigor.

The polygalacturonase enzyme shows greater activity in the cotyledons as the level of moisture in D. nigra seeds increases, independently of the temperature.

\section{Acknowledgements}

The authors thank the PROCAD Amazonia Project: "Physiology and biochemistry of seeds of Amazonian forest species".

\section{References}

BASKIN, C.C.; BASKIN, J.M. Seeds: ecology, biogeography and evolution of dormancy and germination. San Diego: Academic Press. 666p. 1998.

BLACK, M.; CORBINEAU, F.; GRZESIK, M.; GUY, P.; COME, D. Carbohydrate metabolism in the developing and maturing wheat embryo in relation to its desiccation tolerance. Journal of Experimental Botany, v.47, n.295, p.161-169, 1996. http://jxb.oxfordjournals.org/content/47/2/161

BORGES, E.E.L.; RENA, A.B. Germinação de sementes. In: AGUIAR, I.B.; PIÑA-RODRIGUES, F.C.M.; FIGLIOLIA, M.B. (Coord.). Sementes florestais tropicais. Brasília: ABRATES, 1993. p.83-136.

BORGES, E.E.L.; PEREZ, S.C.J.G.A.; BORGES, R.C.G.; REZENDE, S.T.; GARCIA, S.R. Comportamento fisiológico de sementes osmocondicionadas de Platymiscium pubescens Micheli (tamboril-da-mata). Revista Árvore, v.26, n.5, p.603-613, 2002a. http://www.scielo.br/scielo.php?script=sci_artt ext\&pid $=$ s0100-67622002000500011

BORGES, E.E.L.; BORGES, R.C.G.; SOARES, C.P.B.; PEREZ, S.C.J.G.A. Crescimento e mobilização de carboidrato em embrião de sementes de fedegoso (Senna macranthera Irwin et Barneby) durante a germinação. Cerne, v.8, n.1, p.6976, 2002b. http://redalyc.uaemex.mx/redalyc/html/744/74408107/744081075.html

BUCKERIDGE, M.S.; DIETRICH, S.M.C. Mobilization of the raffinose family oligosaccharides and galactomannan in germinating seeds of Sesbania marginata Benth. (Leguminosae-Faboideae). Plant Science, v.117, n.1, p.3343, 1996. http://www.sciencedirect.com/science/article/pii/016894529604410x 
BUCKERIDGE, M.S.; TINÉ, M.A.S.; SANTOS, H.P.; LIMA, D.U. Polissacarídeos de reserva de parede celular em sementes: estrutura, metabolismo, função e aspectos ecológicos. Revista Brasileira de Fisiologia Vegetal, v.12, n.esp., p.137-162, 2000. http://www.cnpdia.embrapa.br/rbfv/ pdfs/download.php?file=v12especialp137.pdf

BUCKERIDGE, M.S.; SANTOS, H.P.; TINÉ, M.A.S.; AIDAR, M.P. Mobilização de reservas. In: FERREIRA, A.G.; BORGHETTI, F. Germinação: do básico ao aplicado. Porto Alegre: Artmed, 2004. 324p.

CARVALHO, P.E.R. Espécies arbóreas brasileiras - volume 1. Colombo: Embrapa Florestas, 2003.1039p.

CROMARTY, A.S.; ELLIS, R.H.; ROBERTS, E.H. The design of seed storage facilities for genetic conservation. Rome: International Board of Plant Genetic Resources, 1990. 109p.

DONADIO, N.M.M.; DEMATTÊ, M.E.S.P. Morfologia de frutos, sementes e plântulas de canafístula (Peltophorum dubium (Spreng.) Taub.) e jacarandáda-bahia (Dalbergia nigra (Vell.) Fr. All. ex Benth.) - Fabaceae. Revista Brasileira de Sementes, v.22, n.1, p.64-73, 2000. www.abrates.org.br/revista/ artigos/2000/v22n1/artigo10.pdf

ENGLYST, H.N.; CUMMINGS, J.H. Simplified method for the measurement of total non-starch polysaccharides by gas-liquid chromatograph of constituent sugars as alditol acetates. Analyst, v.109, n.1, p.973-942, 1984. http://pubs.rsc.org/en/content/articlelanding/1984/an/an9840900937

FERRAZ-GRANDE, F.G.A.; TAKAKI, M. Temperature dependent seed germination of Dalbergia nigra Allem (Leguminosae). Brazilian Archives of Biology and Technology, v.44, p.401-404, 2001. http://www.scielo.br/scielo. php?script $=$ sci_arttext\&pid=s1516-89132001000400010

FIALHO, L.S.; GUIMARÃES, V.M.; CALLEGARI, C.M.; REIS, A.P.; BARBOSA, D.S.; BORGES, E.E.L.; MOREIRA, M.A.; REZENDE, S.T. Characterization and biotechnological application of an acid $\alpha$-galactosidase from Tachigali multijuga Benth. seeds. Phytochemistry, v.69, n.14, p.25792585, 2008. http://www.ncbi.nlm.nih.gov/pubmed/18834998

GHIANI, A.; ONELLI, E.; AINA, R.; COCUCCI, M.; CITTERIO, S. A comparative study of melting and non-melting flesh peach cultivars reveals that during fruit ripening endo-polygalacturonase (endo-PG) is mainly involved in pericarp textural changes, not in firmness reduction. Journal of Experimental Botany, v.62, n.11, p.4043-4054, 2011. http://jxb. oxfordjournals.org/.../jxb.err109.full.pdf

GUIMARÃES, V.M.; REZENDE, S.T.; MOREIRA, M.A.; BARROS, E.G.; FELIX, C.R. Characterization of $\alpha$-galactosidases from germinating soybean seed and their use for hydrolysis of oligosaccharides. Phytochemistry, v.58, n.1, p.67-73, 2001. http://www.sciencedirect.com/science/article/pii/ s0031942201001650

IBAMA - Lista Oficial de Flora ameaçada de extinção. http://www.ibama. gov.br/flora/extincao.htm. Acesso em: 02. mai. 2010.

KANAI, M.; NISHIMURA, M.; AYHASHI, M. A peroxisomal ABC transporter promotes seed germination by inducing pectin degradation under the control of ABI5. Plant Journal, v.62, n.6, p.936-947, 2010. http://www. ncbi.nlm.nih.gov/pubmed/20345608

KUO, T.M.; VANMIDDLESWORTH, J.F.; WOLF, W.J. Content of raffinose oligosaccharides and sucrose in various plant seeds. Journal of Agricultural and Food Chemistry, v.36, n.3, p.32-36, 1988. http://naldc.nal.usda.gov/ download/24213/pdf
LORENZI, H. Árvores brasileiras: manual de identificação e cultivo de plantas arbóreas nativas do Brasil. Nova Odessa: Plantarum, 1992.

MAGALHÃES, S.M.; BORGES, E.E.L.; BERGER, A.P. Alterações nas atividades das enzimas alfa-galactosidade e poligalacturonase e nas reservas de carboidratos de sementes de Schizolobium parahyba (Well) Blake (guapuruvú) durante a germinação. Revista Brasileira de Sementes, v.31, n.2, p.253-261, 2009. http:// www.scielo.br/scielo.php?pid=s0101-31222009000200030\&script=sciarttext

MAGUIRE, J.D. Speed of germination: aid in selection and evaluation for seedling emergence and vigour. Crop Science, v.2, n.2, p.176-177, 1962. https:// www.agronomy.org/publications/cs/abstracts/2/2/cs0020020176/preview/pdf

MILLER, G.L. Use of dinitrosalicylic acid reagent for determination of reducing sugar. Analytical Chemistry, v.31, n.3, p.426-428, 1959. http://pubs. acs.org/doi/abs/10.1021/ac60147a030

MOLLE, F.R.D.; TINÉ, M.A.S. Catabolismo de sacarose durante a mobilização do galactomanano e sua importância na estratégia de sobrevivência de plântulas de Sesbania virgata (Cav.) Pers. Hoehnea, v.36, n.2, p.259-268, 2009. www. ibot.sp.gov.br/publicacoes/hoehnea/.../Hoehnea362T4.pdf

NONOGAKI, H.; CHEN, F.; BRADFORD, K.J. Mechanisms and genes involved in germination sensu stricto. In: BRADFORD, K.J.; NONOGAKI, H. Seed development, dormancy and germination. Ames: Blackwell Publishing, 2007. p.264-304.

OLIVEIRA JÚNIOR, L.F.G.; BRESSAN-SMITH, R.; OLIVEIRA, A.E.A.; PEREIRA, M.G.; SILVA, L.B.; VIANA, L.H.; VIEIRA, H.D. Insulina e glicose como moduladores do desenvolvimento de plântulas de milho doce (Su1). Acta Botanica Brasilica, v.23, n.3, p.751-755, 2009. http://www. scielo.br/scielo.php?pid=s0102-33062009000300014\&script=sciarttext

POLOWICK, P.L.; BALISKI, D.S.; BOCK, C.; RAY, H.; GEORGES, F. Over-expression of $\alpha$-galactosidase in pea seeds to reduce raffinose oligosaccharide content. Botany, v.87, n.6, p.526-532, 2009. http://www. nrcresearchpress.com/doi/abs/10.1139/b09-020

RODRIGUES, A.C.; HERTER, F.G.; VERÍSSIMO, V.; CHAVARRIA, G.; GARDIN, J.P.P.; CAMPOS, A.D. Determinação por cromatografia gasosa de açúcares em frutíferas de clima temperado. Revista Brasileira de Fruticultura, v.27, n.1, p.173-174, 2005. www.scielo.br/pdf/rbf/v27n1/24595.pdf

SITRIT, Y.; HADFIELD, K.A.; BENNETT, A.B.; BRADFORD, K.J.; DOWNIE, A.B. Expression of a polygalacturonase associated with tomato seed germination. Plant Physiology, v.121, n.2, p.419-428, 1999. http://www. plantphysiol.org/content/121/2/419.full

STATSOFT, Inc. Statistic (data analysis sot ware system), Version 7. 2008. www.statsoft.com.

SUDA, C.N.K.; BUCKERIDGE, M.S.; GIORGINI, J.F. Cell wall hydrolases in the seeds of Euphorbia heterophylla L. during germination and early seedling development. Brazilian Journal of Plant Physiology, v.15, n.3, p.135-143, 2003. http://www.scielo.br/scielo.php?script=sci_art text\&pid=s1677-04202003000300002

SWAIN, S.; KAY, P.; OGAWA, M. Preventing unwanted breakups: using polygalacturonases to regulate cell separation. Plant Signaling \& Behavior, v.6, n.1, p.93-97, 2011. http://www.ncbi.nlm.nih.gov/pmc/articles/pmc3122015/ 